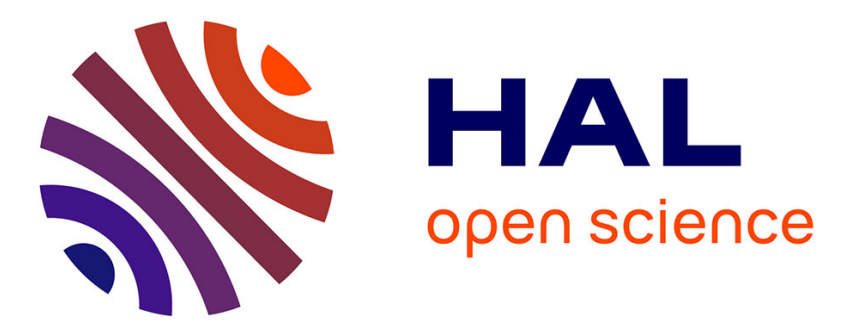

\title{
Smart regions. Two cases of crowdsourcing for regional development
}

Steffen Roth, Jari Kaivo-Oja, Thomas Hirschmann

\section{To cite this version:}

Steffen Roth, Jari Kaivo-Oja, Thomas Hirschmann. Smart regions. Two cases of crowdsourcing for regional development. International Journal of Entrepreneurship and Small Business, 2013, 20 (3), pp.272-285. hal-01053527

\section{HAL Id: hal-01053527 \\ https://hal.science/hal-01053527}

Submitted on 31 Jul 2014

HAL is a multi-disciplinary open access archive for the deposit and dissemination of scientific research documents, whether they are published or not. The documents may come from teaching and research institutions in France or abroad, or from public or private research centers.
L'archive ouverte pluridisciplinaire HAL, est destinée au dépôt et à la diffusion de documents scientifiques de niveau recherche, publiés ou non, émanant des établissements d'enseignement et de recherche français ou étrangers, des laboratoires publics ou privés. 


\title{
Smart regions: two cases of crowdsourcing for regional development
}

\section{Steffen Roth*}

ESC Rennes School of Business,

2 rue Robert d'Abrissel, 35000 Rennes, France

E-mail: steffen.roth@esc-rennes.fr

*Corresponding author

\section{Jari Kaivo-Oja}

University of Turku,

Rehtorinpellonkatu 3, 20500 Turku, Finland

E-mail: jari.kaivo-oja@utu.fi

\section{Thomas Hirschmann}

\author{
We Are Social GmbH, \\ Klenzestraße 38, 80469 München, Germany \\ E-mail: thomas.hirschmann@wearesocial.net
}

\begin{abstract}
Despite a certified need for stronger ties between regional entrepreneurial ecosystems and larger networks, and despite an emerging discourse on beneficial interlinks between crowdsourcing and urban development, the relationship between crowdsourcing and regional development is underexplored. Unlike the few existing reports on voluntary bottom-up crowdsourcing initiatives for regional development, the focus of the present article is on two cases of top-down initiatives of crowdsourcing for regional development launched by institutional actors in the Swiss Canton of Valais and the Italian autonomous province, South Tyrol. The results of a comparison of the two cases suggest consideration of the strength of regional ties as factors that undermine crowd wisdom and flow as well as exercising caution with quantitative idea selection processes, at least in the context of smaller regional crowdsourcing projects.
\end{abstract}

Keywords: crowdsourcing; smart cities; smart regions; regional development; entrepreneurial ecosystem.

Reference to this paper should be made as follows: Roth, S., Kaivo-Oja, J. and Hirschmann, T. (2013) 'Smart regions: two cases of crowdsourcing for regional development', Int. J. Entrepreneurship and Small Business, Vol. 20, No. 3, pp.272-285.

Biographical notes: Steffen Roth is an Assistant Professor of Management and Organization at the ESC Rennes School of Business, France. He was awarded a $\mathrm{PhD}$ in Management from Chemnitz University of Technology, and recently submitted another $\mathrm{PhD}$ thesis to the Department of Sociology at the University of Geneva. He held visiting professorships at the University of Cagliari, the Copenhagen Business School, and the Yerevan State University. His research fields include organisational theory, functional differentiation, ideation and crowdsourcing and culturomics. 


\begin{abstract}
Jari Kaivo-Oja is one of the leading foresight experts and innovation management researchers in the Nordic countries. He has worked in numerous EU Commission projects in the 6th and the 7th Framework programs. He is an Adjunct Professor at the University of Helsinki and the University of Lapland. He has worked for the European Commission, for the European Foundation, for the Nordic Innovation Center (NIC), for the Finnish Funding Agency for Technology and Innovation (TEKES), for the EUROSTAT, for the RAND Europe, and for the European Parliament. Currently, he works in cooperation with the Chinese Academy of Social Sciences (CASS) in the field of global energy and climate policy. His research activities are focused on foresight tools and methodologies, on innovation research and management, on global sustainability, knowledge and ubiquitous society developments, global energy and climate change policies, modern management research and governance theories.
\end{abstract}

Thomas Hirschmann is a Key Account Director at We Are Social GmbH, Munich and $\mathrm{PhD}$ student in Business Psychology at the University of Mannheim. His research interests include creativity, innovation, social capital, social value, crowdsourcing and open innovation processes.

\title{
1 Introduction: smart cities, weak regions?
}

Crowdsourcing has become a widely adopted form of open innovation in various industries. As we know, national innovation systems are key elements of economic growth in any national economy. Today, national innovation systems are open systems because of the wider acceptance of the open innovation paradigm. The development from information society to knowledge society, and now to ubiquitous society, is one grand driver for the need of crowdsourcing and associated techniques and methods in regional development planning and policy. The internet as an infrastructure of service economy is already now a hard-fact of social and regional development (Westerlund and Kaivo-Oja, 2012). Social media and, in the future, ubimedia, will increase the strategic importance of crowdsourcing. Strategic intelligence of many organisations is currently already based on the techniques of crowdsourcing. More and more innovations are nowadays based on the contributions of larger masses of people (Santonen et al., 2011; Kaivo-oja and Santonen, 2010). In this context, crowdsourcing seems to be a promising strategy of integrating users from remote areas of the global innovation society, including the emerging markets as well as more peripheral world regions (Roth, 2010).

Despite the many good reasons for crowdsourcing and the increasing awareness of the need for stronger ties between regional entrepreneurial ecosystems and larger networks (Malecki, 2011; Van Geenhuizen and Soetanto, 2012), the interlink between crowdsourcing ecosystems as particular forms of innovation ecosystems (Nambisan and Baron, 2012) and regional development has, at this point, hardly been discussed. This is even more surprising against the background of the emerging discourses on beneficial interlinks between crowdsourcing and urban development. Today, the intelligence and creativity of urban knowledge spaces or the overall smartness of cities (Komninos, 2009; Schaffers et al., 2011; Angelidou et al., 2012; Mechant et al., 2012) seems to depend much on the respective policy-makers' openness to recent and future trends in e-collaboration, IT-based open innovation, and the mass-integration of users or 
inhabitants willing to contribute ideas or generate content or services. In contrast to the few existing reports that focus on voluntary bottom-up crowdsourcing initiatives for regional development (Murgante et al., 2011), the present article will focus on two cases of top-down initiatives for crowdsourcing for regional development.

Subsequent to a presentation of forms and functions of crowdsourcing processes in general, the article will focus on existing interfaces of crowdsourcing and urban development before presenting evidence for the existence of crowdsourcing projects for regional development launched by institutional actors in the regions of the Valais, Switzerland, and South Tyrol, Italy.

\section{Crowd wisdom: innovation processes and crowdsourcing}

In 1998, the US multinational pharmaceutical corporation Eli Lilly created an InnoCentive. Eight years later, Jeff Howe wrote his famous blog article in Wired Magazine about the phenomena he labelled as crowdsourcing (Howe, 2006). After that breakthrough year, general interest in crowdsourcing has increased in the form of innovation process or innovation management. Over the past decade, there has been growing public interest in the complex connections of modern society. The rapid growth of the internet and the web has made many forms of communication easier and faster. In addition, ordinary people have better access to the internet. They also have improved skills and motivation to utilise the communication capacity of the web and the internet. These and further driving forces, including digital technological evolution, socio-cultural tribalism, and globalisation, make the crowdsourcing phenomena stronger and more relevant for many stakeholders. In fact, though often overlooked, crowdsourcing today is an essential part of global communication and marketing operations. When seriously discussing consumer-driven innovation management, it is important to acknowledge that it cannot occur without professionally practicing some kind of crowdsourcing. This aspect of user integration and mass participation is also discussed in terms of the democratisation of production, service development, and information exchange (Easley and Kleinberg, 2012).

In general, more combined capabilities are needed in a modern innovation process (Teece, 1986, 2006). Crowdsourcing can help to combine capabilities and allows stakeholders to evaluate the scale and scope of new potential innovations (Chandler, 1990). If, by means of a crowdsourcing process, an economic actor can find that a potential innovation is likely to have good scope and scale, it is much easier to motivate risk investors and other fund raisers to invest in this special idea with favourable characters (Teece, 1993). Thus, crowdsourcing can be considered a risk management tool for innovators and other stakeholders of innovation.

There are many alternative ways to crowdsource. One way to identify key phases of crowdsourcing was presented by Prather (2009), who noted the key phases of the innovative problem-solving process, which are stated as follows:

- the challenge and its definition/s

- mind mapping

- brainstorming

- pattern breaking 
- $\quad$ presentation of better solution proposals

- $\quad$ idea pool and mapping processes (evaluation of value and capability to realise ideas)

- $\quad$ present final, improved ideas.

In a crowdsourcing process, large numbers of ideas are produced and then filtered in a systemic way. The challenge of crowdsourcing must also be relevant and important. There must not be an easy or obvious solution to a challenge. Participants of crowdsourcing should be committed to solving challenges.

There are many other models available, but this Bottom Line Innovation ${ }^{\mathrm{r}}$ model helps us to discuss the functions of crowdsourcing. Based on this BLI model, we can follow the preceding steps:

1 define challenges of crowdsourcing

2 mind map good ideas and solutions to challenges

3 brainstorm and filter ideas and solutions and, finally

4 apply the most improved ideas to challenges.

We can say that these are minimal functions of crowdsourcing. As further key functions of crowdsourcing, aspects, such as market research and user generation of content and services, are considered. In all these fields, crowdsourcing is said to produce fast, cost efficient, and high quality solutions to a broad scope of problems (Pénin and Burger-Helmchenm 2011; Schenk and Guittard, 2011; Barbier et al., 2012).

In general, we can see many advantages in crowdsourcing, as it achieves the following:

- gives possibilities and voices for workers and idea creators inside organisations

- $\quad$ is an effective tool for consumer-driven innovations

- $\quad$ gives incentives for active and innovative workers on a grassroots level

- channels innovative thinking towards business success and rewards

- may help many organisations in the log-frogging process

- helps organisations and companies to develop their innovation capacity to become bigger and more extensive.

Crowdsourcing can be applied within many social contexts: organisations, markets, networks, crowds, and regional contexts. The crowdsourcing process can be either virtual or real. Crowdsourcing is closely related to, but not the same process as, human-based computation, which refers to the ways in which humans and computers work together to solve problems. Crowdsourcing can include the following:

- man-to-man

- man-to-machine/robot (in real life processes)

- man-to-avatar (in virtual environments)

- machine-to-machine oriented process

- avatar-to-avatar process. 
Nowadays, crowdsourcing is typically a man-to-machine process. A computing machine can be an avatar or a robot (Coleman, 2011). Thus, crowdsourcing can connect to First World and Second World environments (Roth, 2010). We can therefore also identify different levels of spatial reality on micro or niche levels, on meso-level of socio-technical regimes, and on landscape or global levels (Geels, 2002, 2004, 2005a, 2005b). We can note that crowdsourcing is also potentially can also be a part of a regional transition management process. In addition, the development process of systemic innovations can benefit considerably from crowdsourcing. These spatial levels are relevant for transition management of systemic innovations as various research articles clearly indicate, whether directly or indirectly (Geels, 2006, 2007b, 2007a; Geels and Kemp, 2007; Geels and Schot, 2007; Autio et al., 2008).

\section{Smart regions: linking crowdsourcing and innovation ecosystems}

Today, growing numbers of people in an increasing number of world regions have contributed a number of bright and fresh ideas regarding new ways to improve existing processes. For many organisations, a key challenge is how to organise team creativity and harvest ideas (Adair, 2007). Typical innovation processes start with many ideas before people transform the new ideas into inventions, and, finally, turn inventions into novel innovations. Crowdsourcing, networking, and marketing operations can, thus, be instantly blended in multiples ways to create successful innovation process. The distinctions between crowdsourcing, marketing operations, and networking are increasingly blurring. Crowdsourcing can be used in the development of technological innovations, business model innovations, and social innovations. In addition, media plays an important role in crowdsourcing processes when asking big audiences to reflect popular issues and problematic questions (Inkinen and Kaivo-Oja, 2009). Whenever we can involve larger numbers of people in an innovation process, the acceptance of the developed ideas will rise along with the likelihood that inventions are turned into innovations. A typical problem is that individual inventors do not see the true value of their ideas and they do not want anyone to help them. Thus, the deficit of crowdsourcing expertise causes big social and economic losses for companies as well as urban or regional economies. The lack of crowdsourcing capacity can lead to larger scale negative externalities, thus, decreasing the productivity and efficiency of markets, companies, and corporations. These efficiency and productivity gap problems are well known to limit what is called the 'smartness' of cities and regions (Asheim and Gertler, 2005; Doloreux and Parto, 2005).

Consequently, spatial scales, time horizons, and social impacts of crowdsourcing may vary. Some crowdsourcing processes can be very brief; some can be very time-consuming. As well, some can have very large-scale dimensions, while others operate on a smaller scale when scales are regionally defined. It is very important to understand relevant scale in both the spatial and time dimension. When we analyse our case studies, we pay special attention to spatial scale and time scale. As a typical innovation process includes fundamental re-organisations in the physical, temporal, and social reality (Roth, 2009; Pine and Korn, 2011), crowdsourcing processes aim to be short-term and spatially extensive rather than long-run processes with small spatial scale.

Today, smartness is a typical goal of technological development. Many R\&D experts talk about smart technologies. The highest level of smartness is expected to be reached by ubiquitous technologies. In the information society phase of development, the key issue 
was to transform data into information. In the knowledge society phase of development, the key issue was to transform information to knowledge. In the ubiquitous society phase, the key challenge will be to transform knowledge to wisdom, often referred to in terms of value propositions for customers, stakeholders, for the common good, or sometimes even human kind. Thus, only developing technical innovations for customers is a very limited approach to smartness. When we talk about smart cities and regions, we must add further aspects to smartness, such as smart business models or smart social innovations. Accordingly, the integration of large numbers of urban (or regional) actors in terms of crowdsourcing can be observed (Kaivo-Oja, 2010; Westerlund and Kaivo-Oja, 2012; Kaivo-Oja, 2011).

In urban contexts, one of the most basic notions governing the structure of social networks is homophily. The principle of homophily indicates to behavioural code that we tend to be similar to our friends. Our friends do not look like a random sample of the underlying urban population. We like to see similar kinds of friends around us. Typically, there is similarity of age, sex, occupations, affluence, opinions, beliefs, ethnic background, and interests. The pervasive truth is that links in a social network tend to connect people who are similar to one another. Selection and social influence are key forces behind homophily (Easley and Kleinberg, 2007). Crowdsourcing help us to identify various forms of networking and homophily. A typical problem in many marketing analyses is that varieties of homophily are not identified. These kinds of simple marketing approaches can lead us to traditional group thinking problems and organisational biases. If we want to avoid such biases, professional crowdsourcing allows us to eliminate many dangerous biases in strategic decision-making, marketing, and innovation management.

\section{Two smart regions: crowdsourcing for the Valais and South Tyrol}

Despite the existing discourse on the impact of crowdsourcing on urban smartness (Angelidou et al., 2012; Schaffers et al., 2011; Komninos, 2009), and despite the well-known needs for connecting local regional entrepreneurial ecosystems to larger networks of innovation (Van Geenhuizen and Soetanto, 2012; Malecki, 2011), the interlink between crowdsourcing ecosystems as particular forms of innovation ecosystems (Nambisan and Baron, 2012) and regional development has hardly been discussed so far. In contrast to the few existing reports that focus on voluntary bottom-up crowdsourcing initiatives for regional development (Murgante et al., 2011), the present article presents two cases of the use of crowdsourcing platforms as an element of 'smart' development strategies for regional development and the design of entrepreneurial ecosystems.

\subsection{The regions}

Though being located in two different countries, Switzerland and Italy, the regions of the Valais (VS) and South Tyrol (ST) display a number of similarities, making them comparable. With less than 320,000 inhabitants and a size of 5,224 $\mathrm{km}^{2}$ and some 510,000 living on a territory of $7,400 \mathrm{~km}^{2}$, respectively, both the VS $\left(61 / \mathrm{km}^{2}\right)$ and ST $\left(69 / \mathrm{km}^{2}\right)$ are thinly populated. Both region names can be considered strong brand names, which is not least due to their picturesque locations in the heart and at the southern face 
of the Central European Alps, respectively. Both regions are therefore popular vacation destinations with issues of expanding their regional brand beyond the tourism industry. Politically and culturally speaking, both multi-lingual ${ }^{1}$ mountain regions ${ }^{2}$ feature a considerable amount of self-awareness and autonomy: The VS is on of the 26 Cantons of Switzerland, i.e., one of the once sovereign member states of the Swiss Confederacy, who still maintains a comparably high degree of independence. Though just a province of one out of the many traditionally hardly independent regions of the unitary Republic of Italy, ST cultivates a nimbus of independence as expressed in the official name Autonome Provinz Bozen (Autonomous Province of Bolzano). This claim of autonomy is rooted in the region's Austrian heritage and the dominance of the German language, and at least partly supported by the Italian Government in terms of a high level of self-government compared to other Italian provinces or regions. Both in the VS and in ST, the comparably high degree of regional autonomy is also reflected in terms of a rather independent educational system. In the case of the VS, however, this autonomy did not lead to the establishment of an own cantonal university. The VS only supports a bilingual university of applied sciences, ${ }^{3}$ which recently merged with other Universities of Applied Sciences (UAS), which are located in the French-speaking part of Switzerland, to form the University of Applied Sciences Western Switzerland. In terms of trans-regional cooperation, the VS is also predominantly directed to the French-speaking part of Switzerland. By contrast, ST promotes its membership in the international Euroregion Tyrol-ST-Trentino, which corresponds to the current margins of the historical region of Tyrol located on both sides of the Italian-Austrian border. In terms of the independent, tri-lingual $^{4}$ Free University of Bozen-Bolzano, ST strategically cultivates its multilingualism and cultural ambitions.

In both regions, regional actors and institutions support multi-contest crowdsourcing platforms with a focus on regional development.

\section{2 iBrain: crowdsourcing for the VS}

iBrain (i-brain.ch) is a crowdsourcing community of officially more than $2,000^{5}$ members who contribute solutions to problems or answers to questions related to the development of the Canton of VS. The platform's software architecture represents a mass-customised version of the architecture designed and used by the Atizo AG - Switzerland's leading crowdsourcing service provider - for Atizo's own crowdsourcing platform.

In July 2011, the operators of iBrain, the Institute of Entrepreneurship Management (IEM) of the University of Applied Sciences Western Switzerland branch VS (HEV), launched the first ideation project on their platform. Contributors were asked to contribute ideas of what giveaways and souvenirs could support the development of the brand VS. In return, a cash reward of CHF 1,000 was promised for the best idea(s). In total, 77 were contributed and the reward split between two ideas, each of which had been contributed by two users who had used the forum accrowin.ch in order to mobilise large amounts of support as well as agreed to share the prize money with among themselves. ${ }^{6}$ In terms of content, the winning ideas proposed to design a gift bundle of vouchers for regional events and products as well as a puzzle whose pieces are discount vouchers for tourist activities and regional products.

The subsequent two projects were run in Chinese because the IEM aimed at bringing crowdsourcing to China and agreed to use the platform for corresponding tests. 
The forth ideation project focused on 'summer activities to practice in the mountain of Crans-Montana'. The project was supported by the Crans-Montana Skiing Domain and moderated by its marketing manager, who is a business partner and likely a relative to the responsible manager of iBrain at the IEM. ${ }^{7}$ The non-cash prizes promised were ski passes with a total value of CHF 2,000. Again, one of the above mentioned users took a considerable share of the prizes after having mobilised support from accrowin.ch. ${ }^{8}$ This time, however, the top two ideas out of 177 (transformation of cable car cabins into locations for romantic dinners and tasting hikes from alp to alp) were contributed by students of the HEV and the University of Lausanne, who are (now) personally known to the head of the IEM and the iBrain manager.

While the fifth project represented a self-application of the platform along the question of 'How could we give more value to your points of innovation?', i.e., a symbolic reward offered to good ideas in cases where no prizes are awarded, the sixth project was headlined 'Which are the innovative ideas for tomorrow's tourism in the VS?' The prize for the best idea out of 164 was a touchscreen, which the moderator of the project, a professor at the IEM, handed over to one his colleagues, i.e., the marketing manager of the HEV, who had recently joined the school and proposed a campaign with the title 'Valais Expérience', which represents an appealing bundle of VS-related tourist events. After two additional self-applications, the currently running ninth project is about ideas of how to celebrate the bicentennial anniversary of the Accession of the VS to the Helvetic Confederation. The project is moderated by the Service for Economic Development of the Canton of VS. So far, more than 70 ideas have been submitted.

\subsection{Open innovation Südtirol: crowdsourcing for ST}

Open Innovation Südtirol (openinnovation-suedtirol.it, OIS) is a crowdsourcing platform for SME in the Italian province of ST. The platform is operated by the Regional Crafts Association (Landesverband der Handwerker, LHV) and supported by the Province government, a regional technology park, a consulting company, and the University of Innsbruck. Its architecture is based on a mass-customisable software solution created by the Munich crowdsourcing service provider Hyve AG. The project has limited funding by the European Regional Development Fund, however, will be continued when funding flows out in autumn 2013. The overall aim of the initiative is to increase the innovative capacities of the regional crafts industry with a particular focus on concept, design, and marketing innovations as well as the development of stronger ties between the craftsmen and a general culture of knowledge transfer.

The launch of the platform was in May 2012. The challenge of the pilot project as suggested by the carpentry Heinrich Hofer was in finding sophisticated, sustainable, and useful souvenirs made of wood. After the project duration of nine weeks, 149 members had contributed 296 ideas. Three months after the start, a jury - consisting of representatives of the regional industry, the South Tyrol Marketing Association, and the LHV as well as two marketing professors - had chosen three winning ideas. The first prize of $€ 1,500$ was awarded to the Milanese architects office STUDIOSVS for its wooden model of a South Tyrolean mountain village. The second prize $(€ 1,000)$ went to a user named Chris (Raetzer), who suggested halving billets of classy woods and scooping a fit for wine bottles. The resulting product made from the recomposed wood contained a good bottle of wine, and was considered a noble give-away. A Bolzano architect received the third prize $(€ 500)$ for her model of a Dolomite-shaped doorstop. 
From June to July 2012, the LHV launched a public call for tenders. Small and medium craft industries based in ST were invited to articulate problems or questions related to their businesses. The platform managers then granted selected candidates access to the platform and a community of 522 partially international members. ${ }^{9}$

The South Tyrolean painting company Moling $\mathrm{GmbH}$ was chosen to contribute problems and questions for the second idea and design competition. Moling was looking for packing design and marketing ideas for a wax cement product recently invented by the company. Forty-nine ideas were contributed. This time, the jury consisted of the owner of the Moling $\mathrm{GmbH}$, a South Tyrolean architect, representatives of the OIS-platform designer Hyve AG and the LHV, and a marketing professor from the University of Innsbruck. The draft designs developed by a user named $\mathrm{C}-\mathrm{a}$ design student from the Münster University of Applied Sciences - and a Veronese user named Luca were selected for the first three prizes $(€ 1,500, € 1,000, € 500)$. News coverage again focused on the jury rather than the prizewinners.

In the currently running third project, the South Tyrolean timber company Holzmar has called for draft designs or models of the wooden house of the future. Except for the company representative and a newly added hotelier, the same persons as in the second project hotelier hold the jury chairs. One hundred and seventy-two ideas have been contributed, two of which have already been highlighted at OISs Facebook site.

\subsection{Discussion}

Comparing the two cases, we find that both operators rely on software designed by professional crowdsourcing service providers, which is not only useful in terms of adequate usability, but also in terms of community import. In the iBrain case, the platform initially received a considerable number of contributions by users of the platform atizo.com, which is operated by the designer of iBrains IT-architecture, Atizo AG. Subsequent to a number of issues related to the conformability and fairness of the distribution of prizes, the larger part of Atizo users seem to have withdrawn from iBrain. In the case of OIS, the platform also benefitted from contributions by user forwarded by the Hyve AGs own website.

Though both iBrain and OIS have a clear regional focus, it seems as if OIS is more open towards contributions from users-based outside ST as indicated by the fact that at least $50 \%$ of the prizes have been won by users not based in the province. This circumstance may have been supported by the transparency of the jury composition, the selection process, and the communication of the jury's decisions. In the case of iBrain, however, both the jury and the selection process is unknown to the users ${ }^{10}$ and there is certain evidence for mutuality in situations where colleagues and relatives pass projects and prizes among each other. In addition, the self-presentation of the Swiss platform sometimes reads as if the focus of the initiative is to generate showcases that help the operators to eventually generate turnaround with crowdsourcing projects for individual SME business partners rather than to contribute to regional development. ${ }^{11}$ 


\section{Conclusions: crowdsourcing between small-scale money laundering and large-scale regional development}

As indicated by the two cases, crowdsourcing has a certain potential to increase the innovative capacities as well as the density of ties and the knowledge transfer within regional systems. Regional smartness in terms of crowdsourcing for regional development does not stop at implementing reliable and intuitive IT solutions for crowdsourcing. Both cases presented in this article represent platform architectures customised by professional crowdsourcing service providers. The analysis of the cases suggests a focus on both the social embedding of the IT process into the regional context and the internal coherence and fairness of the crowdsourcing process itself.

The initiative around the Swiss platform iBrain makes a case for the validity of the homophily principle (Easley and Kleinberg, 2007) or the in-/famous strength of the regional ties. Both factors may act as flow killers and lead to regional lock-ins even in a context that is supposed to contribute to regional innovation openness. In fact, the presented examples of mutuality in the context of the selection and rewarding of ideas may be considered a reason why the platform is likely to fail at its mission of connecting the Canton of VS with larger networks of innovation. By contrast, the Italian platform OIS - has a strong focus on regional problems and questions, however, not on regional solutions as indicated by the larger share of rewarded contributions by foreign users. Even with regard to the regional self-orientation, the South Tyrolean case displays a higher degree of diversity awareness: While iBrain is an initiative of the IEM of the Valais University of Applied Sciences, the OIS projected is borne by a blend of political, economic, educational, and scientific institutions. This broader embedding seems to help to avoid or at least reduce the influence of self-serving interests and biased concepts of regional development. In fact, the integration of further institutions, namely religious, aesthetic, legal, or health related institutions, could lead to even broader scopes of problem definitions and, thus, solutions (Roth 2012; Santonen et al., 2011).

Still, as both platforms represent examples of smaller crowdsourcing projects, the case(s) of crowdsourcing for regional development not only call(s) for more research on particular balances between weak and strong ties, but also for the critical mass of crowdsourcing in general. Looking at crowds of hardly 800 or 600 people against the background of the widely assumed 1-9-90-rule, ${ }^{12}$ the first, but not only, crucial question in regional crowdsourcing is as follows: How much crowd is in crowdsourcing? If crowdsourcing projects for regional development are predominantly used by people who already know each other in order to store ideas, legitimate yet made decisions, or exchange favours, then the emerging link between crowdsourcing and regional development will be broken before authorities are able to reveal whether or not crowdsourcing projects have the potential to launder money. If, however, regional actors realise that the scale of a crowdsourcing project depends on the scope of the problem and therefore cannot stop at the regional horizon of interests (thus, avoiding the homophily trap), then crowdsourcing for regional development can indeed increase a region's smartness in terms of increased skills in both IT-based knowledge sharing and the design of value generating social relationships. 


\section{References}

Adair, J. (2007) Leadership for Innovation: How to Organize Team Creativity and Harvest Ideas, Kogan Page, London.

Angelidou, M., Gountaras, N. and Tarani, P. (2012) 'Engaging digital services for the creation of urban knowledge ecosystems: the case of Thermi, Greece', International Journal of Knowledge-Based Development, Vol. 3, No. 4, pp.331-350.

Asheim, B. and Gertler, M. (2005) 'The geography of innovation', in Fagerberg, T., Mowery, D.C. and Nelson, R.R. (Eds.): The Oxford Handbook of Innovation, pp.291-317, Oxford University Press, Oxford.

Autio, E., Kanninen, S. and Gustafsson, R. (2008) 'First-and second-order additionality and learning outcomes in collaborative R\&D programs', Research Policy, Vol. 37, No. 1, pp.59-76.

Barbier, G., Zafarani, R., Gao, H., Fung, G. and Liu, H. (2012) 'Maximizing benefits from crowdsourced data', Computational \& Mathematical Organization Theory, Vol. 18, No. 3, pp.1-23.

Chandler, A.D. (1990) Scale and Scope, Cambridge Univ. Press, Cambridge.

Coleman, B. (2011) Hello Avatar: Rise of the Networked Generation, MIT Press, Boston.

Doloreux, D. and Parto, S. (2005) 'Regional innovation systems: current discourse and unresolved issues’, Technology in Society, Vol. 27, No. 2, pp.133-153.

Easley, D. and Kleinberg, J. (2007) The Small-World Phenomenon, Networks, Spring.

Easley, D. and Kleinberg, J. (2012) Networks, Crowds, and Markets: Reasoning About a Highly Connected World, Cambridge University Press, New York.

Geels, F. (2006) 'Co-evolutionary and multi-level dynamics in transitions: the transformation of aviation systems and the shift from propeller to turbojet (1930-1970)', Technovation, Vol. 26, No. 9, pp.999-1016.

Geels, F.W. (2002) 'Technological transitions as evolutionary reconfiguration processes: a multi-level perspective and a case-study', Research Policy, Vol. 31, No. 8, pp.1257-1274.

Geels, F.W. (2004) 'From sectoral systems of innovation to socio-technical systems: insights about dynamics and change from sociology and institutional theory', Research Policy, Vol. 33, No. 6, pp.897-920.

Geels, F.W. (2005a) 'The dynamics of transitions in socio-technical systems: a multi-level analysis of the transition pathway from horse-drawn carriages to automobiles (1860-1930)', Technology Analysis \& Strategic Management, Vol. 17, No. 4, pp.445-476.

Geels, F.W. (2005b) Technological Transitions and System Innovations: A Co-Evolutionary and Socio-Technical Analysis, Edward Elgar Publishing, Cheltenham.

Geels, F.W. (2007a) 'Feelings of discontent and the promise of middle range theory for STS examples from technology dynamics', Science, Technology \& Human Values, Vol. 32, No. 6, pp.627-651.

Geels, F.W. (2007b) 'Transformations of large technical systems a multilevel analysis of the Dutch Highway System (1950-2000)', Science, Technology \& Human Values, Vol. 32, No. 2, pp.123-149.

Geels, F.W. and Kemp, R. (2007) 'Dynamics in socio-technical systems: typology of change processes and contrasting case studies', Technology in Society, Vol. 29, No. 4, pp.441-455.

Geels, F.W. and Schot, J. (2007) 'Typology of sociotechnical transition pathways', Research Policy, Vol. 36, No. 3, pp.399-417.

Howe, J. (2006) 'The rise of crowdsourcing', Wired, Vol. 14, No. 14, pp.1-5.

Inkinen, S. and Kaivo-Oja, J. (2009) 'Understanding innovation dynamics', Aspects of Creative Processes, Foresight Strategies, Innovation Media and Innovation Ecosystems, eBook, Vol. 9.

Kaivo-Oja, J. (2010) 'Systemic innovation thinking as a tool for breakthrough innovations', edited by E. Laaksonen. 
Kaivo-Oja, J. (2011) Futures of Innovation Systems and Systemic Innovation Systems: Towards a Better Innovation Quality with New Innovation Management Tools, University of Turku, Turku.

Kaivo-Oja, J. and Santonen, T. (2010) 'Open innovation in a systemic innovation context: analyzing online mass innovation process from systemic perspectives', Frontiers of Open Innovation, Vol. 69, Research Report 225, Lappeenranta University of Technology.

Komninos, N. (2009) 'Intelligent cities: towards interactive and global innovation environments', International Journal of Innovation and Regional Development, Vol. 1, No. 4, pp.337-355.

Malecki, E.J. (2011) 'Connecting local entrepreneurial ecosystems to global innovation networks: open innovation, double networks and knowledge integration', International Journal of Entrepreneurship and Innovation Management, Vol. 14, No. 1, pp.36-59.

Mechant, P., Stevens, I., Evens, T. and Verdegem, P. (2012) 'E-deliberation 2.0 for smart cities: a critical assessment of two 'idea generation' cases', International Journal of Electronic Governance, Vol. 5, No. 1, pp.82-98.

Murgante, B., Tilio, L., Scorza, F. and Lanza, V. (2011) 'Crowd-cloud tourism, new approaches to territorial marketing', Computational Science and Its Applications-ICCSA 2011, pp.265-276.

Nambisan, S. and Baron, R.A. (2012) 'Entrepreneurship in innovation ecosystems: entrepreneurs' self-regulatory processes and their implications for new venture success', Entrepreneurship Theory and Practice, 5 June, DOI: 10.1111/j.1540-6520.2012.00519.x.

Nielsen, J. (2006) 'Participation inequality: encouraging more users to contribute', Jakob Nielsen's Alertbox, 9 October.

Pénin, J. and Burger-Helmchen, T. (2011) 'Crowdsourcing of inventive activities: definition and limits', International Journal of Innovation and Sustainable Development, Vol. 5, No. 2, pp.246-263.

Pine, B.J. II and Korn, K.C. (2011) Infinite Possibility: Creating Customer Value on the Digital Frontier, Berrett-Koehler Publishers, San Francisco.

Prather, C. (2009) The Manager's Guide to Fostering Innovation and Creativity in Teams, McGraw-Hill, New York.

Roth, S. (2009) 'New for whom? Initial images from the social dimension of innovation', International Journal of Innovation and Sustainable Development, Vol. 4, No. 4, pp.231-252.

Roth, S. (2010) 'The diaspora as a nation's capital: crowdsourcing strategies for the Caucasus', International Journal of Transitions and Innovation Systems, Vol. 1, No. 1, pp.44-58.

Roth, S. (2012) 'The moral of functional differentiation: a new horizon for descriptive innovation ethics', Electronic Journal of Business Ethics and Organization Studies, Vol. 17, No. 2, pp.27-34.

Santonen, T., Kaivo-Oja, J. and Antikainen, M. (2011) 'National open innovation systems (NOIS): defining a solid reward model for NOIS', International Journal of Innovation and Regional Development, Vol. 3, No. 1, pp.12-25.

Schaffers, H., Komninos, N., Pallot, M., Trousse, B., Nilsson, M. and Oliveira, A. (2011) 'Smart cities and the future internet: towards cooperation frameworks for open innovation', The Future Internet, Lecture Notes in Computer Science, Vol. 6656, pp.431-446.

Schenk, E. and Guittard, C. (2011) 'Towards a characterization of crowdsourcing practices', Journal of Innovation Economics, No. 1, pp.93-107.

Teece, D.J. (1986) 'Profiting from technological innovation: Implications for integration, collaboration, licensing and public policy', Research Policy, Vol. 15, No. 6, pp.285-305.

Teece, D.J. (1993) 'The dynamics of industrial capitalism: perspectives on Alfred Chandler's scale and scope', Journal of Economic Literature, Vol. 31, No. 1, pp.199-225.

Teece, D.J. (2006) 'Reflections on 'profiting from innovation', Research Policy, Vol. 35, No. 8, pp.1131-1146. 
Van Geenhuizen, M. and Soetanto, D.P. (2012) 'Benefitting from learning networks in 'open innovation': spin-off firms in contrasting city regions', European Planning Studies, Vol. 21, No. 5, pp.666-682.

Westerlund, L. and Kaivo-oja, J. (2012) 'Digital evolution - from information society to ubiquitous society', in Kuosa, T. and Westerlund, L. (Eds.): Service Design: On the Evolution of Design Expertise, Lahti University of Applied Sciences Series A, Research reports, Part 16, pp.137-153.

\section{Notes}

1 VS: German and French; ST: German, Italian, and Ladin.

2 VS: $372 \mathrm{~m}-4,634 \mathrm{~m}$; ST: $207 \mathrm{~m}-3,905 \mathrm{~m}$.

3 In the Middle European context, UAS are traditionally not considered full universities, but rather teaching institutions focused on the diffusion of practical skills and lacking the right to award PhDs.

4 Courses at the Free University of Bozen-Bolzano are held in German, Italian, and English.

5 As we read the official numbers provided by the platform operator provided at: $\mathrm{http}: / / \mathrm{www}$. iemvalais.ch/institut/prestations/www-i-brain-ch/, 11/12/12). Looking at the number of participants on 11/12/12, however, we find that hardly more than 764 persons have registered, so far.

6 C.f., accrowin.ch, heading: 'Aide entre membre', Sujet N 14615 (user: Cafle, 05/07/2011): "hello comme amélie j'ai proposé 3 idées surhttps://ibrain.atizo.com/la dernière c'est la 83 mon nom est caro fleury, merci de voter pour mes idées ..et pour celle de choupinnette amélie gay. VOTEZ VOTEZT VOTEZ MERCI”; Sujet N 15255 (user: Cafle, 25/07/2011): “Bonjour , comme choupinette grace aux accrowinniens 2 de mes idées ont été sélectionées. Merci de votez pour mes idées sur www. i-brain.ch/valais démarer une évalution puis vous vus connectez et mes idées ce sont les puzzle bons de réductions et le snowup slow up lipstick merci de votre soutien gros becs"; Sujet $N^{\circ} 15691$ (user: Cafle, 03/08/2011): "génial bravo amélie bravo valais anne...maintenant que la chace continue et partageons nous la prime valais! sur i-brain/valais merci de voter pour l'idée d'amélie en démarant une évaluation elle c'est la obox et moi caro c'est le puzzle bons de réductions et le lipstick slow up snow up merci".

7 Both persons are limited partners of the Ladex Service Sàrl, Sion, have the same family name, and are born at the same place.

8 C.f., accrowin.ch, heading: 'Aide entre membre', Sujet N`25025 (user: Cafle, 29/03/2012): "coucou amis acrowinniens 3 de mes idees ont été retenue sur ibrain pour gagner des places au caprice festival ou du ski . j'aimerais bcp y aller le samedi soir avec mon homme cel nous ferait un moment sympa tout les deux! si vous evaluez les idees vous pouvez vous aussi gagne run bon de skimes idees sont. NUIT BELLE ETOILE DE LUXE POUR LES PHOBIQUES DE MOUSTIQUES, FASHION MOUNTAINS SHOW OU DEFILE DE MODE,SUMMER CHILDREN CAPRICE FESTIVAL!vous pouvez aussi voter pour les idées d'une autre accro. CONTES ET LEGENDES merci beaucoup pour votre solidarité et belle journée!ps j'ai découvert ibrain et atizo sur accro en aout "ce sont des sites géniaux pour prposer ses idees!"

9 State of 16/11/2012.

10 Indirectly, we learn from the reading of the strategic discussions the first prizewinners held at accrowin.ch that the iBrain team seems to follow a quantitative approach to idea selection. The very context of this finding, however, gives reason for a skeptical attitude to quantitative idea selection techniques, as the participants can obviously manipulate them.

11 At least the presentation of both the platform and the project content reads a little something like this: "Vous souhaitez utiliser iBrain dans votre entreprise pour créer une communauté avec vos employés, vos clients, vos fournisseurs ou d'autres partenaires ? Vous souhaitez défier nos étudiants en leur proposant un challenge interne à votre entreprise ? Leur créativité 
vous aidera surement !Quelques exemples de Brainstormings lancés par des PME : Activités estivales à pratiquer dans les montagnes de Crans-Montana // Quelles idées innovantes pour le tourisme valaisan de demain? // Vos idées pour fêter le Bicentenaire du Valais le vendredi 7 août 2015". (You want to use iBrain in your enterprise in order to create a community with your employees, your suppliers or other partners? You want to tempt your students to meet your internal business challenges? Their creativity will surely help you! Some examples of brainstormings launched by SME: ...; source: website of the IEM, available at: http://www.iemvalais.ch/institut/prestations/www-i-brain-ch/).

12 Within social media networks or communities, a 1-9-90 rule is supposed to apply: $1 \%$ of the community members are fully engaged, $9 \%$ are contributing sporadically, and $90 \%$ are just consuming the flow of information and debate (Nielsen, 2006). 